\title{
CDISC SDTM Marital Status Terminology
}

National Cancer Institute

\section{Source}

National Cancer Institute. CDISC SDTM Marital Status Terminology. NCI Thesaurus.

Code C76348.

Terminology codelist used for Marital Status within the Clinical Data Interchange Standards Consortium Study Data Tabulation Model. 